\title{
Audit Mutu Hukum Pengaturan dan Penerapan Pertanggungjawaban Sosial Bank Melalui Program One Village One Company (OVOC) terhadap Badan Usaha Milik Desa (BUMDes) di Jawa Barat
}

\author{
Tri Putri Natalia \\ Fakultas Hukum Universitas Padjadjaran \\ Correspondence email: putrynataliasimanjuntak@gmail.com
}

\begin{abstract}
Abstrak. Pemprov Jabar berupaya untuk membantu kemandirian desa guna meningkatkan perekonomian masyarakat desa dengan mencanangkan program OVOC. Dasar hukum mengenai program OVOC terangkum dalam suatu kesepakatan bersama yang dibentuk antara Pemprov Jabar dengan Bank BJB. Penulisan ini akan mengkaji bagaimana tanggung jawab Pemprov Jabar sebagai pemangku kepentingan terhadap pelaksanaan program OVOC. Permasalahan hukum yang selanjutnya adalah mengenai pertanggungjawaban sosial lembaga perbankan melalui program OVOC ditinjau dari kesepakatan bersama yang telah terbentuk. Terdapat beberapa ketimpangan antara isi kesepakatan bersama dengan kenyataan yang terjadi di lapangan, salah satunya dana yang masih tersendat di Pemprov Jabar untuk BUMDes di Jawa Barat. Hasil penulisan ini menunjukkan bahwa audit mutu hukum terhadap kesepakatan bersama mengenai program OVOC harus dilaksanakan mengingat terdapat 7 (tujuh) kriteria mutu yang harus diperhatikan untuk kepentingan para pihak yang terlibat didalamnya. Dalam keterkaitannya dengan lembaga perbankan, seharusnya lembaga perbankan turut andil dalam pelaksanaan peningkatan kapasitas, pendampingan teknis, dan pemanfaatan fasilitas layanan perbankan sebagai wujud tanggung jawab sosial atas program OVOC.
\end{abstract}

Kata Kunci: One Village One Company, Kesepakatan Bersama, Badan Usaha Milik Desa, Pemerintah Daerah Provinsi Jawa Barat, Lembaga Perbankan.

\begin{abstract}
West Java Provincial Government seeks to help the independence of the village in order to improve the economy of rural communities by launching the OVOC program. The legal basis for the OVOC program is summarized in a joint agreement formed between the West Java Provincial Government and the BJB Bank. This writing will examine the responsibilities of the West Java Provincial Government as a stakeholder in the implementation of the OVOC program. The next legal issue is the social responsibility of banking institutions through the OVOC program in terms of the mutual agreement that has been formed. There are some gaps between the contents of the joint agreement with the reality that is happening on the ground, one of which is funds that are still stalled in the West Java Provincial Government for BUMDes in West Java. The results of this paper indicate that a legal quality audit of a joint agreement regarding the OVOC program must be carried out bearing in mind there are 7 (seven) quality criteria that must be considered for the interests of the parties involved in it. In its relationship with banking institutions, banking institutions should contribute to the implementation of capacity building, technical assistance, and utilization of banking service facilities as a form of social responsibility for the OVOC program.
\end{abstract}

Keywords: One Village One Company, Joint Agreement, Village-Owned Enterprises, West Java Provincial Government, Banking Institutions.

\section{PENDAHULUAN}

Pemerintah Daerah Provinsi Jawa Barat (Pemprov Jabar) terus berupaya membantu kemandirian desa untuk meningkatkan perekonomian masyarakat desa. Salah satu langkah yang dilakukan diantaranya mencanangkan program One Village One Company (OVOC). Menurut Gubernur Jabar, Ridwan Kamil, inisiatif munculnya program OVOC adalah akibat daripada masih terjadinya ketimpangan antara desa dengan kota Jabar. Tidak tergalinya potensi desa membuat warga desa lebih memilih pergi ke kota untuk mencari pekerjaan. Bilamana di setiap desa sudah terdapat minimal satu perusahaan yang memanfaatkan potensi desa tersebut, tentu hal ini akan sangat membantu warga sekitar untuk mendapatkan pekerjaan dan penghasilan. Pada dasarnya desa sudah memiliki BUMDes, tetapi hal ini tidak akan menjadi permasalahan karena konsep antara BUMDes dengan OVOC itu berbeda, OVOC disini akan mencari pasar terlebih dahulu sehingga produk yang dihasilkan akan mudah terjual. ${ }^{1}$

Pengertian dari OVOC sendiri adalah payung program yang bertujuan untuk memandirikan desa dengan optimalisasi potensi sumber daya, baik manusia dan alamnya, melalui pemanfaatan BUMDes. OVOC berusaha menggeser pola pikir pembinaan menjadi pendampingan desa dan penguatan sinergi multi-stakeholder desa, agar desa mendayagunakan potensinya untuk kemandirian desa. Dalam pencapaiannya, visi OVOC terdiri dari Patriot Desa, Pendampingan BUMDes, dan Sekolah CEO. ${ }^{2}$

\footnotetext{
1"One Village One Company" (2019) < https://ovoc.jabarprov.go.id/?route=moreart\&artid=12> [25 September 2019].

"“One Village One Company” (2019) <https://ovoc.jabarprov.go.id/?route=tentang> [25 September 2019].
} 
Mengatasi permasalahan ekonomi makro dapat dilakukan melalui program OVOC. Peneliti akan menjabarkan setiap permasalahan ekonomi makro dimulai dari inflasi, yang dimaksud dengan inflasi adalah suatu keadaan dimana terdapat kecenderungan kenaikan harga-harga secara umum dan terus menerus. ${ }^{3}$ Menurut opini Penulis, keadaan inflasi dapat dihapus melalui program OVOC dengan alasan bahwa program OVOC menghasilkan produk-produk berkualitas dan dibutuhkan setiap saat oleh masyarakat banyak, sehingga pendapatan masyarakat yang dihasilkan berbasis program OVOC tidak akan terhambat, justru akan menciptakan peningkatan efisiensi ekonomi, pun memberikan peluang untuk masyarakat dalam hal perekonomian.

Selanjutnya persoalan kedua, yaitu masalah pengangguran. Pengangguran ini terjadi karena jumlah tenaga kerja atau angka kerja melebihi tingkat kesempatan kerja yang tersedia. ${ }^{4}$ Ketika penduduk di suatu desa bergabung dengan program OVOC, secara otomatis mereka akan dituntut untuk mencipatakan suatu usaha yang sederhana namun bernilai. Biasanya, mereka memiliki usaha berbasis kearifan lokal, dimana memang di daerah tersebut terdapat faktor alam yang kiranya cocok untuk dijadikan produk yang nantinya akan diperjualbelikan dalam cakupan pasar yang lebih luas. Dengan demikian, permasalahan pengangguran akan lekas berkurang.

Berjalan lancarnya program OVOC tidak terlepas dari bantuan lembaga perbankan untuk desa-desa dibawah BUMDes Pemprov Jabar, dimana desa yang bersangkutan adalah desa yang sudah maju dan berkembang. Dasar hukum yang menjadi acuan untuk melaksanakan program OVOC adalah Kesepakatan Bersama Antara Pemerintah Daerah Provinsi Jawa Barat dengan PT. Bank Pembangunan Daerah Jawa Barat dan Banten, TBK. Tentang Percepatan Peningkatan Pembangunan dan Pemberdayaan Perekonomian Masyarakat Melalui Pemanfaatan Fasilitas Layanan Perbankan Nomor: 119/17/DPM-DESA/008/NK/DIR-INS/2018 (yang selanjutnya disebut dengan Kesepakatan Bersama antara Pemprov Jabar dengan Bank BJB).

Penulis menemukan beberapa persoalan hukum berdasarkan seluruh fakta yang telah terangkum diatas. Yang pertama, Penulis akan mengkaji bagaimana tanggung jawab Pemprov Jabar sebagai pemangku kepentingan terhadap pelaksanaan program OVOC. Persoalan hukum yang selanjutnya adalah mengenai pertanggungjawaban sosial lembaga perbankan melalui program OVOC ditinjau dari pengaturan terhadap Kesepakatan Bersama antara Pemprov Jabar dengan Bank BJB, yang diantaranya adalah peningkatan kapasitas melalui pelatihan pengelolaan bisnis penguatan Lembaga Perekonomian Masyarakat oleh Bank BJB dan pendampingan teknis penguatan Lembaga Perekonomian Masyarakat oleh Bank BJB. Hasil wawancara Penulis dengan salah satu staff Dinas Pemberdayaan Masyarakat (DPM) Desa Jabar adalah BUMDes belum bisa mendapatkan penyertaan modal berupa aliran dana karena belum memenuhi persyaratan dalam proposal, seperti tidak bisa membuat rincian keuangan dengan benar. Oleh karena itu, DPM Desa Jabar merasa khawatir terhadap BUMDes dalam mengelola keuangan, karena desa dianggap belum berkompeten dalam menerima modal.

Penulis melihat adanya ketimpangan antara isi Kesepakatan Bersama dengan kenyataan yang terjadi, dalam hal ini terdapat ketimpangan antara das sollen (apa yang seharusnya) dan das sein (apa yang terjadi pada kenyataannya), sehingga diperlukannya audit mutu hukum sebagai bentuk dari efektivitas BUMDes yang didukung program OVOC dengan tujuan untuk mengatasi permasalahan yang timbul akibat dari ketimpangan tersebut. Audit mutu hukum merupakan salah satu parameter yang digunakan untuk mengedit atau merevisi hukum. ${ }^{5}$ Lazimnya, audit mutu hukum digunakan untuk masalah keuangan, sehingga yang akan lebih spesifik dibahas dalam penelitian ini adalah mengenai karakter pertanggungjawaban sosial Bank BJB yang diarahkan untuk mewujudkan kesejahteraan. Seharusnya, Bank BJB ikut berperan dalam melakukan pendampingan dan sosialisasi. Penulis akan mengkaji lebih lanjut terkait kebutuhan apa saja yang kiranya dibutuhkan BUMDes diluar pengaturan Kesepakatan Bersama yang telah terbentuk dan melihat pandangan dari lembaga perbankan terkait program OVOC. Setelah mengaudit Kesepakatan Bersama tersebut, Peneliti akan menganalisis permasalahan yang terjadi dan menuangkannya ke dalam Perjanjian dalam bentuk Kesepakatan Bersama sebagai perbaikan dari pengaturan kesepakatan yang sebelumnya.

Berdasarkan uraian yang terdapat pada latar belakang diatas, maka Penulis akan membatasi permasalahan yang akan dibahas dalam penelitian ini sebagai berikut:

1. Bagaimanakah tanggung jawab Pemerintah Daerah Provinsi Jawa Barat sebagai pemangku kepentingan terhadap pelaksanaan program One Village One Company (OVOC)?

2. Bagaimanakah pengaturan terhadap Kesepakatan Bersama antara Pemerintah Daerah Provinsi Jawa Barat dengan Bank BJB dalam hal pertanggungjawaban sosial lembaga perbankan melalui program One Village One Company (OVOC) ditinjau dari Audit Mutu Hukum?

\footnotetext{
${ }^{3}$ Priyono Teddy Chandra, Esensi Ekonomi Makro, Surabaya: Zifatama Publisher, 2016, hlm. 5.

${ }^{4}$ Ibid, hlm. 6.

5 Tarsisius Murwaji, “Audit Mutu Hukum dan Mitigasi terhadap Badan Usaha Milik Petani sebagai Wujud
} Pertanggungjawaban Sosial Perusahaan Menghadapi ASEAN-CHINA Free Trade Area”, LITIGASI Jurnal Ilmu Hukum, Vol. 13, No. 2, Oktober 2012, hlm. 1439. 
Kemudian tujuan dari penelitian ini sendiri yaitu untuk mengkaji dan menganalisis bagaimana tanggung jawab Pemerintah Daerah Provinsi Jawa Barat sebagai pemangku kepentingan terhadap pelaksanaan program One Village One Company (OVOC) dan untuk mengkaji dan mengevaluasi bagaimana pengaturan terhadap Kesepakatan Bersama antara Pemerintah Daerah Provinsi Jawa Barat dengan Bank BJB dalam hal pertanggungjawaban sosial lembaga perbankan melalui program One Village One Company (OVOC) ditinjau dari Audit Mutu Hukum.

\section{METODE PENELITIAN}

Metode penelitian merupakan uraian teknis yang digunakan dalam penelitian. ${ }^{6}$ Adapun metode penelitian yang digunakan dalam penelitian ini adalah sebagai berikut :

\section{Metode Pendekatan Penelitian}

Penelitian ini menggunakan metode pendekatan yuridis normatif, yaitu metode penelitian hukum yang dilakukan dengan cara meneliti bahan pustaka atau data sekunder saja. Penelitian hukum normatif atau kepustakaan mencakup penelitian terhadap asas-asas hukum, sistematik hukum, taraf sinkronisasi hukum, sejarah hukum, dan perbandingan hukum. ${ }^{7}$ Secara spesifik metode pendekatan yang digunakan adalah pendekatan perundang-undangan (statue approach) yaitu dilakukan dengan menelaah undang-undang dan regulasi yang bersangkutan terpaut dengan isu hukum yang sedang ditangani. ${ }^{8}$ Penelitian ini menggunakan data primer sebagai data utama, teori-teori, dan konsepkonsep yang berhubungan dengan permasalahan yang terdapat di BUMDes Jabar dan UMKM yang telah atau sedang melaksanakan program OVOC dan tetap dikaitkan dengan kaidah-kaidah hukum. Hal tersebut bertujuan untuk meneliti penerapan aspek-aspek hukum dalam tanggung jawab pertumbuhan ekonomi, pelaksanaan BUMDes Jabar dan UMKM yang melaksanakan program OVOC, serta pelaksanaan pertanggungjawaban sosial lembaga perbankan terhadap BUMDes Jabar dan UMKM yang terlibat dalam program OVOC diaudit dari Perjanjian Kerjasama antara Pemprov Jabar dengan Bank BJB.

\section{Rancangan Kegiatan}

Penelitian ini merupakan penelitian yuridis normatif. Dalam penelitian yuridis normatif, dilakukan terhadap kaidah-kaidah hukum yang merupakan patokan-patokan berperilaku atau bersikap tidak pantas. Penelitian tersebut dapat dilakukan (terutama) terhadap bahan hukum primer dan sekunder, sepanjang bahan-bahan tadi mengandung kaidahkaidah hukum.

Dengan demikian, dalam penelitian ini hukum normatif yang digunakan pada rancangan kegiatan yang dilakukan oleh Peneliti yaitu dalam hal mengevaluasi pengaturan Kesepakatan Bersama antara Pemprov Jabar dengan Bank BJB dalam hal pertanggungjawaban sosial lembaga perbankan adalah Undang-Undang Perbankan, UndangUndang UMKM, Peraturan Menteri Desa, dan Audit Mutu Hukum.

\section{Bahan dan Alat Utama \\ Bahan Hukum Primer}

Bahan hukum primer adalah bahan-bahan hukum yang dijadikan dasar dalam menyusun penulisan skripsi yang diambil dari kepustakaan diantaranya:

1. Undang-Undang Dasar Negara Republik Indonesia Tahun 1945;

2. Kitab Undang-Undang Hukum Perdata (KUHPerdata);

3. Undang-Undang Nomor 10 Tahun 1998 tentang Perbankan;

4. Undang-Undang Nomor 20 Tahun 2008 tentang Usaha Mikro, Kecil, dan Menengah;

5. Peraturan Menteri Desa, Pembangunan Daerah Tertinggal, dan Transmigrasi Republik Indonesia Nomor 4 Tahun 2015;

6. Kesepakatan Bersama Antara Pemerintah Daerah Provinsi Jawa Barat dengan PT. Bank Pembangunan Daerah Jawa Barat dan Banten, TBK. Tentang Percepatan Peningkatan Pembangunan dan Pemberdayaan Perekonomian Masyarakat Melalui Pemanfaatan Fasilitas Layanan Perbankan Nomor : 119/17/DPM-DESA/008/NK/DIRINS/2018.

7. Peraturan lain yang relevan dengan penelitian.

\section{Bahan Hukum Sekunder}

1. Buku-buku literatur yang relevan dengan judul skripsi ini.

\footnotetext{
${ }^{6}$ Bahder Johan Nasution, Metode Penelitian Ilmu Hukum, Bandung: CV. Mandar Maju, 2016, hlm. 3.

${ }^{7}$ Soerjono Soekanto dan Sri Mamudji, Penelitian Hukum Normatif Suatu Tinjauan Singkat, Jakarta: Raja Grafindo Utama, 2015, hlm. 114.

${ }^{8}$ Peter Mahmud Marzui, Penelitian Hukum, Jakarta: Prenada Media Group, 2005, hlm. 93.
} 
Tri Putri Natalia, Audit Mutu Hukum Pengaturan dan Penerapan Pertanggungjawaban Sosial Bank Melalui Program One Village One Company (OVOC) terhadap Badan Usaha Milik Desa (BUMDes) di Jawa Barat

2. Makalah-makalah tentang Perbankan, Badan Usaha Milik Desa, Audit Mutu Hukum, dan Omnibuslaw.

\section{Bahan Hukum Tersier sekunder, yakni: \\ 1. Kamus Hukum (Black's Law Dictionary). \\ 2. Kamus Besar Bahasa Indonesia. \\ 3. Ensiklopedia.}

Bahan hukum tersier adalah bahan hukum yang akan digunakan Penulis dalam mendukung bahan hukum

\section{Teknik Pengumpulan Data}

Pengumpulan awal data dilaksanakan dengan melakukan studi kepustakaan yakni dengan mengumpulkan bahan peraturan perundang-undangan, buku, maupun literatur lain yang berkaitan dengan permasalahan yang hendak diteliti. Setelah itu, Peneliti akan melakukan observasi lapangan di BUMDes Pemprov Jabar, Kota Bandung untuk mencari gambaran mengenai permasalahan yang akan diteliti. Serta, Peneliti juga mengikuti rapat di BUMDes Pemprov Jabar terkait program OVOC tersebut.

Setelah melakukan observasi, Peneliti melaksanakan wawancara dengan Kepala Bidang BUMDes Pemprov Jabar yakni dengan mengajukan beberapa pertanyaan mendasar mengenai tata cara yang didasari dengan pandangan pihak terkait tentang pelaksanaan program OVOC ditinjau dari Perjanjian Kerjasama antara Pemprov Jabar dengan Bank BJB, dimana akan diteliti pula mengenai pertanggungjawaban sosial lembaga perbankan terhadap BUMDes Jabar dan UMKM yang terlibat di dalamnya agar program OVOC tersebut dapat terealisasikan sesuai dengan tujuan yang ada demi terciptanya sebuah pertumbuhan ekonomi yang baik.

Pada tahap akhir, Peneliti melakukan penelusuran dokumen baik secara on-line dan/atau off-line yang berkaitan dengan pokok permasalahan. Penelusuran secara on-line dilakukan dengan membuka (browsing) situs internet, berkomunikasi melalui elektronik mail (e-mail), melalui pesan singkat (short message service), dan/atau melalui jaringan telekomunikasi. Sedangkan penelusuran secara off-line dilakukan dengan berkunjung untuk membaca dan membuat catatan dari beberapa perpustakaan, toko buku, meminjam literatur, dan meminta data-data yang diperlukan dari BUMDes Pemprov Jabar. Selanjutnya data yang telah dikumpulkan tersebut diidentifikasi terhadap bahan hukum yang relevan dengan permasalahan. Bahan hukum tersebut diolah dengan membaca, membuat catatan kutipan, dan mengumpulkannya menjadi satu untuk kemudian menjadi data sekunder yang valid.

\section{Teknis Analisis Data}

Teknik analisis data di dalam penulisan skripsi ini dilakukan dalam beberapa tahapan. Tahap pertama adalah mencari unsur-unsur yang terdapat di dalam fakta hukum yang telah ada dan yang menjadi kendala, yaitu kepastian mengenai sudah sejauh mana tanggung jawab sosial lembaga perbankan terhadap BUMDes Jabar dan UMKM yang telah melaksanakan program OVOC. Setelah itu, Peneliti akan mencari korelasi dalam fakta di lapangan dengan undangundang atau dasar hukum yang mengaturnya, dalam hal ini adalah Perjanjian Kerjasama antara Pemprov Jabar dengan Bank BJB dan Undang-Undang Nomor 10 Tahun 1998 tentang Perbankan. Pada tahap terakhir, Peneliti akan menganalisis permasalahan yang ada dengan konstruksi pembahasan hasil penelitian. Pada tahap ini, pengolahan data dianggap optimal apabila data yang telah diperoleh layak dianggap lengkap dan dapat mempresentasikan masalah yang dijadikan objek penelitian.

\section{HASIL DAN PEMBAHASAN}

\section{Tanggung Jawab Pemerintah Daerah Provinsi Jawa Barat Sebagai Pemangku Kepentingan Terhadap} Pelaksanaan Program One Village One Company (OVOC)

Pemprov Jabar melalui BUMDes Jabar merupakan salah satu badan usaha andalan pemerintah dalam meningkatkan kemandirian perekonomian di desa yang bergantung pada kebutuhan dan potensi desa. Pengelolaan BUMDes sepenuhnya dilaksanakan dari masyarakat desa, oleh masyarakat desa, dan untuk masyarakat desa. BUMDes berjalan dengan metode menampung kegiatan-kegiatan ekonomi masyarakat dalam sebuah bentuk lembaga atau badan usaha yang dikelola secara profesional, akan tetapi berdasarkan pada potensi asli desa. Saat ini total desa di Jawa Barat mencapai 5.300 desa dengan bentang dan potensi alam yang berbeda. Dengan kondisi itu, negara wajib hadir dengan menggelontorkan suntikan modal, untuk membantu optimalisasi kekayaan di desa tersebut melalui program OVOC. ${ }^{9}$

Visi OVOC dalam usaha pencapaiannya, terdiri dari program Patriot Desa, Pendampingan BUMDes, dan Sekolah CEO yang akan diuraikan oleh Peneliti sebagai berikut: ${ }^{10}$

\footnotetext{
9 “Berdayakan Desa dengan Program OVOC", $<$ https://ovoc.jabarprov.go.id/?route=moreart\&artid=10 $>[11$ Januari
} 2020].

10 “One Village One Company", < https://ovoc.jabarprov.go.id/> [11 Januari 2020]. 
Tri Putri Natalia, Audit Mutu Hukum Pengaturan dan Penerapan Pertanggungjawaban Sosial Bank Melalui Program One Village One Company (OVOC) terhadap Badan Usaha Milik Desa (BUMDes) di Jawa Barat

\section{Patriot Desa}

Program Patriot Desa Jawa Barat merupakan bagian OVOC dalam rangka merintis BUMDes berbasis potensi desa. Untuk mencapai peningkatan kapasitas kelembagaan masyarakat, kehidupan sosial budaya dan pengembangan partisipasi serta keswadayaan masyarakat, program Patriot Desa menghadirkan pemuda-pemudi yang akan melalui proses seleksi dan pembakalan untuk menjadi fasilitator lapangan yang bertugas melaksanakan pendampingan dengan skema live-in di desa-desa penempatan yang belum memiliki BUMDes yang aktif.

2. CEO BUMDes

Program CEO BUMDes Juara merupakan bagian OVOC dalam rangka mengembangkan BUMDes berbasis karakteristik dan kebutuhan. Melalui pendampingan, mentoring, fasilitasi, stimulasi modal, dan bimbingan teknis diharapkan CEO BUMDes Juara dapat meningkatkan jumlah dan skala usahanya sehingga dapat memberikan dampak pada ekonomi desa secara berkelanjutan.

Tanggung jawab BUMDes Pemprov Jabar sebagai badan yang membawahi dan bertanggungjawab atas seluruh perusahaan, baik berupa koperasi atau UMKM yang menjalankan program OVOC wajib menyusun program rencana kerja kedepan agar perusahaan-perusahaan tersebut mampu mencapai target yang ditetapkan oleh Pemprov Jabar. ${ }^{11}$ Rencana program yang disusun oleh Pemprov Jabar setiap tahunnya, diantaranya yang pertama pada tahun 2019 tersusun Building Foundation. Pada tahun 2020, rencana program yang akan dilaksanakan adalah Starting Up. Selanjutnya pada tahun 2021, rencana program yang akan dilaksanakan adalah Acceleration. Pada tahun 2022, rencana program selanjutnya adalah Scale Up.

Dengan menjalankan beberapa rencana program yang telah dipaparkan diatas, Penulis mengutip dari hasil diskusi dengan BUMDes Pemprov Jabar, perkiraan omset yang didapatkan adalah 10 (sepuluh) juta sampai dengan 1 (satu) miliar per tahun. Jenis usaha yang akan dikembangkan melalui program OVOC adalah kuliner $(0,58 \%)$, simpan pinjam $(12,31 \%)$, perdagangan $(65,32 \%)$, pertanian $(12,58 \%)$, wisata $(2,25 \%)$, agen $(5,58 \%)$, transportasi $(0,78 \%)$, pasar desa $(1,18 \%)$, dan kerajinan $(0,94 \%){ }^{12}$

Finalisasi konsep OVOC menekankan sasaran pada desa yang belum dan telah memiliki BUMDes. Desa yang belum memiliki BUMDes diamanatkan sebuah konsep melalui program Patriot Desa agar melahirkan CEO BUMDes lokal dengan kedudukan "milenial" yang artinya memiliki modal yang cukup besar, memiliki pola pikir yang kreatif, dengan ilmu pengetahuan yang baik, fresh graduate, dan dapat mengikuti perkembangan zaman yang ada di era globalisasi sekarang ini melalui penelusuran potensi desa. Sedangkan desa yang telah memiliki BUMDes, diberikan konsep melalui CEO BUMDes Juara dengan mengembangkan BUMDes melalui mentoring, pendampingan, serta stimulasi modal yang didapatkan dari berbagai pihak terutama dalam hal ini adalah lembaga perbankan. Perlu diketahui bahwa aktivitas program CEO BUMDes untuk program OVOC melalui mentoring oleh CEO BUMDes harus memenuhi kriteria diantaranya telah berpengalaman dalam dunia bisnis dan manajemen, memahami bisnis BUMDes sekaligus berpotensi untuk mengembangkan jejaring BUMDes. CEO BUMDes dalam hal ini pun harus mengidentifikasi kebutuhan pengembangan BUMDes dan menyusun rencana bisnis bagi setiap usaha yang berada dibawah naungannya. CEO BUMDes kerap juga memberikan pendampingan stimulasi permodalan dengan nilai 100 (seratus) juta dan mendampingi pelaksanaan kegiatan secara berkala. Proses yang dilakukan oleh CEO BUMDes untuk menciptakan keadaan BUMDes yang baik adalah dengan mengaktifkan kembali atau mengganti kepengurusan didalam BUMDes terkait, dan kemudian selalu melaporkan perkembangan target kinerja CEO BUMDes dalam proses pencairan gaji. ${ }^{13}$ Stimulasi modal dalam pengembangan BUMDes merupakan salah satu jalan untuk mengembangkan BUMDes melalui bantuan keuangan yang diatur dengan tujuan memperkuat kapasitas kelembagaan, akses permodalan, dan pemasaran.

Tanggung jawab Pemprov Jabar sebagai pemangku kepentingan terhadap pelaksanaan program OVOC melalui CEO BUMDes bertugas untuk mendampingi desa dalam penyelenggaraan pemerintahan desa untuk desa yang lebih maju, menjaga kerjasama antar desa agar turut aktif dalam bidang ekonomi, sosial, dan budaya, CEO BUMDes memberikan arahan dalam hal pengembangan setiap BUMDes agar dapat menjalankan program OVOC dengan sukses, serta memfasilitasi pembangunan berskala lokal desa. Program OVOC juga memberikan percepatan dalam akses keuangan desa, yaitu seluruh transaksi bisnis dan jual beli telah dimodernisasi melalui Internet Corporate Banking dan Rekening Tabungan Masyarakat. Serta permodalan dari stakeholder pun dapat dimanfaatkan oleh setiap desa untuk perluasan bisnis yang berbentuk kredit atau pembiayaan usaha.

Setiap desa tidak dapat berdiri dan bergerak sendiri, melainkan harus ditunjang oleh sebuah badan usaha yang akan mengelola dan melaksanakan kegiatan dari program OVOC ini, yaitu BUMDes. Pendampingan BUMDes melalui program OVOC berfungsi sebagai upaya mendorong desa di Jawa Barat agar mampu mandiri dalam mengelola dan mendayagunakan potensi desa untuk membangun desa dan memberdayakan masyarakat desa. Program OVOC menggeser pemikiran dari pola pembinaan menjadi pola pendampingan. Berdasarkan program OVOC, BUMDes

\footnotetext{
${ }^{11}$ Pasal 5 Kesepakatan Bersama Antara Pemerintah Daerah Provinsi Jawa Barat dengan Bank BJB.

${ }^{12}$ Hasil Diskusi Dinas Pemberdayaan Masyarakat Desa Jawa Barat Mengenai Program One Village One Company.

${ }^{13}$ Ibid.
} 
Pemprov Jabar senantiasa wajib membantu seluruh BUMDes dibawahnya untuk memberikan penyuluhan, mendampingi saat pelaksanaan kegiatan, dan mengawasi jalannya setiap kegiatan yang dilaksanakan sesuai dengan periode waktu yang telah ditetapkan.

Sebelum masuk pada tahap penyuluhan, BUMDes Pemprov Jabar harus melakukan penilaian terhadap desadesa di Jawa Barat dengan klasifikasi desa yang telah cukup baik dan desa yang masih kurang baik dalam hal kesiapan untuk melaksanakan program OVOC ini. Desa yang tergolong pada klasifikasi kurang baik, akan diberikan penyuluhan secara berkala oleh BUMDes Pemprov Jabar kepada BUMDes desa terkait. Sedangkan desa yang sudah tergolong sebagai desa yang baik, akan melanjutkan tahap pelaksanaan kegiatan dengan tetap dibantu oleh perwakilan pusat. Hal tersebut bertujuan untuk meminimalisir sebuah kesalahan yang dilaksanakan oleh BUMDes, serta menciptakan sebuah efisiensi waktu dengan terdapatnya penggolongan desa tersebut.

Pengawasan merupakan salah satu elemen yang sangat penting sebagai wujud implementasi dari pelaksanaan program OVOC. Pengawasan dilakukan oleh BUMDes Pemprov Jabar dengan cara melihat laporan yang diberikan oleh desa-desa di Jawa Barat. Laporan tersebut berupa laporan keuangan, neraca laba dan rugi, laporan praktik kegiatan di lapangan, serta analisis manfaat dan dampak yang dirasakan oleh desa dalam menjalankan kegiatan berdasarkan program OVOC. Jika program OVOC berjalan sesuai dengan visi yang telah dikemas oleh pemerintah, masyarakat akan tetap tinggal di desa dengan pekerjaan yang baik dan menjamin, karena program OVOC dibentuk untuk memangkas ketimpangan antara pedesaan dan perkotaan. ${ }^{14}$

BUMDes Pemprov Jabar memang memiliki hak dan kewajiban sebagai Pemerintah Daerah untuk melaksanakan program OVOC dengan membawahi desa-desa di Jawa Barat, akan tetapi ketika mereka tidak melaksanakan kewajibannya sesuai dengan ketentuan dan/atau kesepakatan yang berlaku (jika mereka membentuk perjanjian dengan para pihak), mereka akan tetap mendapatkan sanksi atau hukuman. Sanksinya adalah melepaskan hak administrasi BUMDes Pemprov Jabar sebagai Pemerintah Daerah untuk melakukan pendampingan terhadap desa-desa di Jawa Barat dalam hal pelaksanaan program OVOC. ${ }^{15}$

\section{Pengaturan Terhadap Kesepakatan Bersama Antara Pemerintah Daerah Provinsi Jawa Barat dengan Bank BJB dalam Hal Pertanggungjawaban Sosial Lembaga Perbankan Melalui Program One Village One Company (OVOC) Ditinjau dari Audit Mutu Hukum}

Pembangunan dan pertumbuhan ekonomi di Indonesia harus terus berjalan dimana dalam hal ini pemerintah melalui BUMDes dan lembaga perbankan turut menyikapi segala sesuatu yang dibutuhkan oleh penduduk Indonesia terutama masyarakat pedesaan dengan mencanangkan program OVOC yang telah terkemas dalam suatu Kesepakatan Bersama antara Pemprov Jabar dengan Bank BJB. Program OVOC pasti tetap menuai pro dan kontra walaupun telah dikonsepkan sebaik mungkin, sehingga dalam hal ini diperlukan forum yang terdiri dari berbagai pihak dan sudut pandang yang berbeda agar menghasilkan suatu solusi yang efektif dan bermanfaat untuk jangka waktu yang panjang. Pada dasarnya, forum ini bertujuan untuk mengaudit atau memeriksa Kesepakatan Bersama yang telah dipaparkan sebelumnya agar tetap saling menguntungkan para pihak yang terlibat di dalamnya serta CEO BUMDes berhasil untuk mengembangkan desa yang terkait dengan cara menggali SDA dan SDM yang dimiliki.

Beberapa badan usaha seperti BUMDes, koperasi, ataupun UMKM yang tidak memiliki dana berlebih dan ditinjau dari Kesepakatan Bersama harus diberikan kemudahan yang salah satunya mendapatkan dana atau kredit dari lembaga perbankan agar mereka tidak kesulitan untuk mengembangkan usaha, bukan hanya untuk di daerah tertentu saja, tetapi mereka harus memiliki prospek usaha yang jelas dengan target penjualan sampai pada bertaraf nasional bahkan internasional. Lembaga perbankan pun dalam hal ini harus berpartisipasi dalam memasarkan produk yang dihasilkan oleh para pelaku usaha yang menjalankan program OVOC, dengan dalih bahwa ketika lembaga perbankan bekerja dalam hal pemasaran, BUMDes, koperasi, atau UMKM dapat menjadi nasabah pada lembaga perbankan terkait, sehingga terjadilah hubungan timbal balik yang menguntungkan dan efektif bagi kedua belah pihak.

Pelaksanaan program OVOC salah satunya diatur dalam Kesepakatan Bersama antara Pemprov Jabar dengan Bank BJB. Dalam Pasal 4 tentang Ruang Lingkup Kesepakatan Bersama memuat aturan mengenai layanan keagenan Laku Pandai, penyaluran fasilitas kredit dan pengelolaan keuangan desa melalui Bank BJB. Dimana, pendanaan yang diberikan oleh Bank BJB masih tersendat atau dalam kata lain belum disalurkan lebih lanjut kepada desa-desa dibawah Provinsi Jabar. Hal tersebut terjadi karena BUMDes Pemprov Jabar masih ragu untuk menyalurkannya saat melihat bahwa desa-desa tersebut tidak dapat memenuhi kriteria untuk mendapatkan penyertaan modal, karena keseluruhan BUMDes tidak lolos dalam membuat proposal. Mereka membuat proposal yang sama sekali tidak memenuhi kriteria, seperti fotokopi Kartu Tanda Penduduk (KTP) yang tidak lengkap, tanda tangan tidak resmi yang hanya berbentuk scan, tidak membuat rincian keuangan, dan lebih tidak masuk akal lagi mereka tidak mendeskripsikan tentang business plan mengenai rencana usaha yang akan mereka jalankan. Oleh karena itu, DPM Desa Jabar cenderung merasa khawatir

${ }^{14}$ Hasil wawancara oleh Dinas Pemberdayaan Masyarakat Desa Provinsi Jawa Barat.

${ }^{15}$ Ibid. 
terhadap BUMDes dalam hal mengelola keuangan, karena desa dianggap belum berkompeten dalam menerima modal. Seharusnya Bank BJB sebelum memberikan modal ikut turut andil melakukan pendampingan teknis secara berkala kepada setiap BUMDes dan memberikan pelatihan dan pengelolaan bisnis untuk mengembangkan potensi mereka agar dapat mengikuti perkembangan globalisasi. Selain yang telah dipaparkan diatas, Peneliti menemukan adanya ketidakpastian hukum dalam isi Kesepakatan Bersama antar Pemprov Jabar dengan Bank BJB, yaitu belum tercantumnya program OVOC beserta aturan-aturan hukumnya.

Menurut pemikiran Peneliti, dengan mengaudit pengaturan terhadap Kesepakatan Bersama antara Pemprov Jabar dengan Bank BJB, akan menemukan beberapa permasalahan yang perlu diperbaiki kedepannya dengan tujuan menunjang keberlanjutan program OVOC tanpa ada ketimpangan antara aturan yang telah dibentuk dengan kenyataan yang ada. Serta memperbaiki beberapa poin dari perjanjian yang telah disebutkan sebelumnya agar tidak ada kerancuan dan berbagai pihak jelas dalam melaksanakan perjanjian tesebut.

Forum CSR ini akan membahas mengenai konsep quadruple helix, dimana konsep ini merupakan model inovasi yang menekankan pada kerjasama antara 4 (empat) unsur yaitu pemerintah daerah atau otoritas publik, industri, universitas atau sistem pendidikan, dan komunitas masyarakat atau pengguna. Empat unsur tersebut bekerjasama secara dinamis dan membentuk helix yang saling berdampingan menuju ke arah pengembangan daerah. Model quadruple helix dapat digunakan sebagai model inovasi daerah dengan konsep kustomisasi disesuaikan dengan kondisi sumber daya yang ada pada daerah itu sendiri. ${ }^{16}$

Penerapan konsep quadruple helix dalam program OVOC sangat diperlukan mengingat peran dan pemikiran pemerintah daerah, BUMDes, koperasi, ataupun UMKM, lalu korporasi dalam hal ini adalah lembaga perbankan, serta masyarakat perlu disatukan untuk kepentingan perekonomian Indonesia.

Berdasarkan karakteristik audit mutu hukum, sejatinya program OVOC harus mengikuti alur dari 7 (tujuh) kriteria yang akan dijelaskan sebagai berikut: ${ }^{17}$

1. Mutu Produk (quality of product)

Mutu produk hukum atau produk jasa hukum dengan simbol (q). Sebagai gambarannya: mutu produk berupa jasa dari pembuat peraturan perundang-undangan dikatakan bermutu apabila peraturan yang telah dibuat dan disahkan tidak ada atau sedikit pihak yang memprotes atau mendesak dicabutnya sehingga peraturan tersebut berlaku dan kurun waktu yang lama.

2. Biaya Minimal (cost)

Biaya yang dikeluarkan seminimal mungkin, dengan simbol (c). Larangan pemerintah kepada Pegawai Negeri Sipil untuk tidak melakukan rapat di hotel merupakan kebijakan pemerintah yang sudah berwawasan mutu karena akan mengurangi biaya rapat. Para pembuat undang-undang dan anggota DPR atau DPRD akan menghemat biaya yang tinggi jika dalam menyusun suatu peraturan dilaksanakan di kantornya dan bukan di hotel.

3. Ketersediaan atau Akses (delivery)

Kemudahan akses untuk mendapatkan pelayanan secara mudah, efektif dan efisien, dengan simbol (d). Akses masyarakat untuk memperoleh informasi dan pelayanan hukum merupakan salah satu indikator mutu. Permasalahan akses ini menjadi permasalahan yang penting karena Indonesia adalah negara kepulauan yang luas.

4. Keamanan (safety)

Produk hukum harus aman dan tidak menimbulkan kesengsaraan, dengan simbol (s). Hukum harus netral, bukan dibentuk untuk kepentingan pembuat undang-undang atau pesanan kelompok tertentu tetapi harus berfungsi memberikan perlindungan kepada seluruh elemen negara, termasuk warga negara.

5. Pelayanan yang Baik (mores)

Saling menghargai antara penyedia jasa dan penyedia jasa, kemudian penyedia jasa dengan pengguna jasa, dengan simbol (m). Dalam teori hukum, memang tidak dibahas tentang keramahan para penegak hukum dalam menjalankan tugasnya. Seringkali polisi, jaksa, hakim, pengacara, dan pejabat publik kurang memperhatikan pelayanan yang ramah sehingga terkesan hukum itu kejam atau tidak bersahabat. Dalam perkuliahan di fakultas hukum perlu dibahas tentang "budaya mutu" yang salah satu unsurnya adalah pelayanan yang ramah sehingga terkesan hukum itu kejam atau tidak bersahabat. Dalam perkuliahan di fakultas hukum perlu dibahas tentang "budaya mutu" yang salah satu unsurnya adalah pelayanan yang ramah.

6. Sistemik (systemic)

Perlu dibentuk sistemnya, dengan simbol (s). Sistem hukum yang dimaksud disini adalah suatu tatanan hukum dalam suatu ilmu atau aturan yang berlaku.

7. Mengikuti Perkembangan atau Trend Masyarakat (Environment)

${ }^{16}$ Widjajani, Arnia Fajarwati, Asep Hidayat, Model Quadruple Helix Sebagai Model Inovasi Daerah (Kajian Literatur), Universitas Langlangbuana, Bandung.

${ }^{17}$ Tarsisius Murwadji, “Integrasi Ilmu Mutu Kedalam Audit Mutu Hukum di Indonesia”, Jurnal Hukum POSITUM, Vol. 1, No. 2, Juni 2017, hlm. 156-158. 
Mengikuti perkembangan masyarakat atau environment diwakilkan dengan simbol (e). Sistem Hukum Nasional harus mengikuti perkembangan hukum global, oleh karena itu pemerintah Indonesia harus aktif mengikuti pertemuan-pertemuan Internasional sehingga pembaharuan hukum dapat dilakukan secara terus menerus. Secara teoritis, dengan demikian untuk menghasilkan wakil rakyat yang berkualitas dan aspiratif, yang salah satunya harus dipilih dengan mekanisme yang baik disertai dengan syarat yang ketat.

Program OVOC adalah sebuah stigma utama dimana pelaksanaannya dilakukan dengan berbagai cara melalui program-program yang turut berkembang dibawahnya. Beberapa program dibawah program OVOC yakni meliputi Patriot Desa, CEO BUMDes Juara, serta Program Talisah yang sudah berjalan selama setahun terakhir ini. Landasan hukum bagi suatu kegiatan, terlebih dalam hal ini kegiatan yang dilakukan adalah program pemerintah sangat penting untuk dirumuskan. Satu aturan sangat berpengaruh terhadap jalannya suatu program, dan untuk membentuk suatu sistem hukum yang efektif dan efisien, pemerintah mencanangkan konsep omnibus law.

Konsep penyederhanaan regulasi melalui omnibus law dilakukan dengan mencabut beberapa regulasi dan menyusunnya kembali dalam satu undang-undang secara menyeluruh, komprehensif, dan sederhana. Dalam sistem pembentukan peraturan perundang-undangan di Indonesia, dimungkinkan perubahan substansi dan pencabutan undangundang oleh undang-undang baru. Menurut pendapat Jimly Asshiddiqie, omnibus law dapat dilakukan melalui kodifikasi hukum, baik terhadap undang-undang maupun peraturan pelaksana di tingkat pusat, sehingga untuk suatu bidang hukum dapat dibukukan dalam 1 naskah yang terpadu. ${ }^{18}$

Berdasarkan seluruh pemaparan diatas, yang akan berpotensi menimbulkan permasalahan hukum atas Kesepakatan Bersama yang dibentuk oleh BUMDes Pemprov Jabar dengan Bank BJB adalah cidera janji atau wanprestasi antar para pihak. Salah satu contohnya adalah kebijakan lembaga perbankan dalam membantu sosialisasi atau pendampingan terhadap BUMDes untuk menunjang pelaksanaan program OVOC ini. Hal ini dapat terjadi apabila desa-desa yang melaksanakan program OVOC tidak tertib dalam melaksanakan hak dan kewajibannya sesuai dengan ketentuan dan/atau kesepakatan yang berlaku, sehingga lembaga perbankan ditakutkan akan mundur ketika melihat tidak terdapat perkembangan pesat program OVOC dalam praktiknya di lapangan.

\section{SIMPULAN}

Berdasarkan uraian yang telah dijelaskan dalam pembahasan, maka Penulis dapat mengambil kesimpulan sebagai berikut:

1. Tanggung jawab Pemerintah Daerah Provinsi Jawa Barat sebagai pemangku kepentingan terhadap pelaksanaan program OVOC. Visi OVOC dalam usaha pencapaiannya, terdiri dari program Patriot Desa, Pendampingan BUMDes, dan Sekolah CEO. Tanggung jawab Pemprov Jabar sebagai pemangku kepentingan terhadap pelaksanaan program OVOC melalui CEO BUMDes bertugas untuk mendampingi desa dalam penyelenggaraan pemerintahan desa untuk desa yang lebih maju, menjaga kerjasama antar desa agar turut aktif dalam bidang ekonomi, sosial, dan budaya, CEO BUMDes memberikan arahan dalam hal pengembangan setiap BUMDes agar dapat menjalankan program OVOC dengan sukses, serta memfasilitasi pembangunan berskala lokal desa. Program OVOC juga memberikan percepatan dalam akses keuangan desa, yaitu seluruh transaksi bisnis dan jual beli telah dimodernisasi melalui Internet Corporate Banking dan Rekening Tabungan Masyarakat. Rencana program yang disusun oleh Pemprov Jabar setiap tahunnya, diantaranya yang pertama pada tahun 2019 tersusun Building Foundation. Pada tahun 2020, rencana program yang akan dilaksanakan adalah Starting Up. Selanjutnya pada tahun 2021, rencana program yang akan dilaksanakan adalah Acceleration. Pada tahun 2022, rencana program selanjutnya adalah Scale Up.

2. Pengaturan terhadap Kesepakatan Bersama antara Pemerintah Daerah Provinsi Jawa Barat dengan Bank BJB dalam hal pertanggungjawaban sosial lembaga perbankan melalui program OVOC ditinjau dari Audit Mutu Hukum. Beberapa badan usaha seperti BUMDes, koperasi, ataupun UMKM yang tidak memiliki dana berlebih dan ditinjau dari Kesepakatan Bersama harus diberikan kemudahan yang salah satunya mendapatkan dana atau kredit dari lembaga perbankan agar mereka tidak kesulitan untuk mengembangkan usaha, bukan hanya untuk di daerah tertentu saja, tetapi mereka harus memiliki prospek usaha yang jelas dengan target penjualan sampai pada bertaraf nasional bahkan internasional. Lembaga perbankan pun dalam hal ini harus berpartisipasi dalam memasarkan produk yang dihasilkan oleh para pelaku usaha yang menjalankan program OVOC, dengan dalih bahwa ketika lembaga perbankan bekerja dalam hal pemasaran, BUMDes, koperasi, atau UMKM dapat menjadi nasabah pada lembaga perbankan terkait, sehingga terjadilah hubungan timbal balik yang menguntungkan dan efektif bagi kedua belah pihak.

${ }^{18}$ Sulasi Rongiyati, Menata Regulasi Pemberdayaan UMKM Melalui Omnibus Law, Jakarta: Pusat Penelitian Badan Keahlian DPR RI, Vol. XI. No. 23, Desember, 2019, hlm. 3. 
Tri Putri Natalia, Audit Mutu Hukum Pengaturan dan Penerapan Pertanggungjawaban Sosial Bank Melalui Program One Village One Company (OVOC) terhadap Badan Usaha Milik Desa (BUMDes) di Jawa Barat

\section{DAFTAR PUSTAKA}

\section{Buku}

Bahder Johan Nasution, Metode Penelitian Ilmu Hukum, Bandung: CV. Mandar Maju, 2016.

Peter Mahmud Marzui, Penelitian Hukum, Jakarta: Prenada Media Group, 2005

Priyono Teddy Chandra, Esensi Ekonomi Makro, Surabaya: Zifatama Publisher, 2016.

Soerjono Soekanto dan Sri Mamudji, Penelitian Hukum Normatif Suatu Tinjauan Singkat, Jakarta: Raja Grafindo Utama, 2015.

\section{Peraturan Perundang-Undangan}

Undang-Undang Dasar Tahun 1945.

Undang-Undang Nomor 10 Tahun 1998 tentang Perbankan.

Undang-Undang Nomor 20 Tahun 2008 tentang Usaha Mikro, Kecil, dan Menengah.

Kitab Undang-Undang Hukum Perdata.

Kesepakatan Bersama Antara Pemerintah Daerah Provinsi Jawa Barat dengan PT. Bank

Pembangunan Daerah Jawa Barat dan Banten, TBK. Tentang Percepatan Peningkatan Pembangunan dan Pemberdayaan Perekonomian Masyarakat Melalui Pemanfaatan Fasilitas Layanan Perbankan Nomor: 119/17/DPMDESA/008/NK/DIR-INS/2018.

Ketetapan MPR Nomor IV/MPR/1999 tentang Ekonomi Kerakyatan.

Peraturan Menteri Desa, Pembangunan Daerah Tertinggal, dan Transmigrasi Republik Indonesia Nomor 4 Tahun 2015.

\section{Internet/Jurnal}

Diskusi Antara Gubernur Provinsi Jawa Barat dengan Dinas Pemberdayaan

Masyarakat Provinsi Jawa Barat Mengenai Program "One Village One Company untuk Desa Perbatasan”.

“One Village One Company”, https://ovoc.jabarprov.go.id, diakses pada tanggal 11 Januari 2020.

Tarsisius Murwadji, "Integrasi Ilmu Mutu Kedalam Audit Mutu Hukum di Indonesia”, Jurnal Hukum POSITUM, Vol. 1, No. 2, Juni 2017.

Tarsisius Murwaji, "Audit Mutu Hukum dan Mitigasi terhadap Badan Usaha Milik Petani sebagai Wujud Pertanggungjawaban Sosial Perusahaan Menghadapi ASEAN-CHINA Free Trade Area”, LITIGASI Jurnal Ilmu Hukum, Vol. 13, No. 2, Oktober 2012.

Widjajani, Arnia Fajarwati, Asep Hidayat, Model Quadruple Helix Sebagai

Model Inovasi Daerah (Kajian Literatur), Universitas Langlangbuana, Bandung.

Sulasi Rongiyati. Menata Regulasi Pemberdayaan UMKM Melalui Omnibus Law. Jakarta: Pusat Penelitian Badan Keahlian DPR RI, Vol. XI No. 23, Desember, 2019. 